\title{
Estimation of Loss of lodine from Edible lodized Salt During Cooking of Various Bangladeshi Food Preparations
}

\author{
K. M. Yasif Kayes Sikdar ${ }^{1}$, Amlan Ganguly ${ }^{2}$, A.S.M. Monjur-Al- Hossain ${ }^{1}$ and \\ A.B.M. Faroque \\ ${ }^{1}$ Department of Pharmaceutical Technology, Faculty of Pharmacy, University of Dhaka, Dhaka-1000, \\ Bangladesh \\ ${ }^{2}$ Department of Clinical Pharmacy and Pharmacology, Faculty of Pharmacy, University of Dhaka, Dhaka-1000, \\ Bangladesh
}

(Received: September 29, 2016; Accepted: October 13, 2016; Published (web): December 27, 2016)

\begin{abstract}
Iodine is one of the essential micronutrients required for the normal mental and physical development of human beings. Low iodine intake exerts several detrimental effects on human health. The most serious effect of iodine deficiency is represented by possible damage to the fetus such as stillbirths, abortions and congenital abnormalities. According to the existing law, iodized salt should contain at least $15 \mathrm{ppm}$ of iodine. However, iodine is lost significantly during cooking and few studies have been conducted to estimate such loss of iodine. Hence, in the present study, thirty recipes commonly cooked in Bangladeshi families were taken and by using colorimetric assay method, it was found that the mean losses of iodine during different cooking procedures were $13.28 \%$ for pressure cooking, $23.46 \%$ for boiling, $9.5 \%$ for deep frying and $5.18 \%$ for shallow frying. The results showed that the loss of iodine depends upon the type of cooking procedures and cooking time.
\end{abstract}

Key words: Iodine deficiency, Colorimetric assay method, Loss of iodine, Cooking procedures, Cooking time

\section{INTRODUCTION}

Iodine is one of the essential micronutrients required for the normal mental and physical development of human beings. ${ }^{1}$ It is a component of the hormones produced by thyroid gland. The tiny quantity of iodine is required every day in the thyroid gland for adequate production of hormones like Triiodothyronine and Thyroxine. Lack of iodine results in deficiency of these hormones and results in a wide spectrum of disorders which is collectively called iodine deficiency disorders (IDD). Iodine deficiency can lead to goiter, cretinism, deafness, dumbness, squint and mental retardation. The most visible and easily recognizable sign of iodine deficiency is goiter. A goiter is an enlarged thyroid gland which can range in sizes from an invisible swelling to a monstrous growth in the throat. Iodine deficiency affects humans at every stage of life and leads to several severe disorders.

Correspondence to: A.B.M. Faroque

Phone: +8801830002826; Email: abmfaroque@yahoo.com

Dhaka Univ. J. Pharm. Sci. 15(2): 161-165, 2016 (December)
More than 90 percent of the populations of 21 developing countries use iodized salt. In 1998, nearly $60 \%$ of world's edible salt was iodized and there was a significant decrease in number of children born at risk of IDD. The number of cretin births halved to less than 55,000 per year. ${ }^{2}$ By 2000, 70 percent of households in developing countries used iodized salt. $^{2}$

Iodized salts stored in atmospheres of relative humidity of 50 percent lose smaller quantities of their iodine than salts stored under similar conditions at other humidity. Universal salt iodization is the recommended intervention for preventing and correcting iodine deficiency. In the past, recommendations for iodine levels in salt were made on the assumption that, from producer to consumer, iodine losses from iodized salt were commonly between $25 \%$ and $50 \%$, and that average salt intakes were commonly between 5 and $10 \mathrm{~g} /$ person/day. Substantial experience has been gained in the last decade in implementing universal salt iodization and 
assessing its impact on iodine deficiency disorders (IDD). A major achievement is the spectacular reduction of IDD in countries that have implemented universal salt iodization. ${ }^{3}$

About $90 \%$ of iodine comes from food while $10 \%$ from water. ${ }^{4}$ There are several regions in the world which have environmental iodine deficiency. Environmental iodine deficiency is caused when iodine present in the upper crust of earth is leached out by heavy rains, repeated flooding and glaciations. ${ }^{5}$ The most commonly used method of prophylaxis against iodine deficiency is via fortification of salt with iodine. ${ }^{6}$ At the beneficiary level iodized salt containing $15 \mathrm{ppm}$ of iodine is supplied. However, still iodine deficiency is observed in mass populations. Hence, a systematic study is undertaken with the objective to assess the loss of iodine during different cooking procedures in various Bangladeshi food preparations.

\section{MATERIALS AND METHODS}

Reagents. Cerric Ammonium Sulfate salt was found from Finoric LLC. Arsenous Oxide was found from American Elements. Other reagents were found from Pharmaceutical Technology Lab, Dhaka University.

Preparation of sample. Some Bangladeshi food recipes were prepared in the kitchen using different cooking procedures like- (1) Pressure cooking, (2)
Shallow frying, (3) Deep frying, and (4) Boiling. All of the raw ingredients were used for preparation of each recipe that was collected and a sample was drawn from them for estimation of their iodine content. This constituted the control group 'A'. The raw ingredients were cooked. A sample was drawn from cooked food, which was constituted the experimental group ' $\mathrm{B}$ '. This procedure was repeated for all the recipes. Equal amounts of sample $\mathrm{A}$ and sample B were collected in triplicates for iodine estimation. Samples of $250 \mathrm{mg}$ of A and B were taken in triplicate in Pyrex test tubes $(15 \times 125 \mathrm{~mm})$. Then $0.3 \mathrm{~mL}$ of sodium carbonate was added. The contents were dried at $110^{\circ} \mathrm{C}$ temperature. The contents were then transferred to a thermostatically controlled muffle furnace and were burned to ashes at $600^{\circ} \mathrm{C}$ for 2 hours. $^{7}$

Preparation of standard curve for Potassium Iodate solution. Various concentration of Potassium Iodate $\left(\mathrm{KIO}_{3}\right)$ solutions were taken in different test tubes. Then $1 \mathrm{~mL}$ of Cerric Ammonium Sulfate solution and then $5 \mathrm{~mL}$ of Arsenous Acid solution were taken in each test tube. The solutions of Cerric Ammonium Sulfate and Potassium Iodate turned colorless after addition of Arsenous Acid solution in each test tube. Then the absorbance of these solutions was measured in UV-VISIBLE Spectrophotometer at the wave length of $415.5 \mathrm{~nm}$. The standard curve was found which is given in Figure 1.

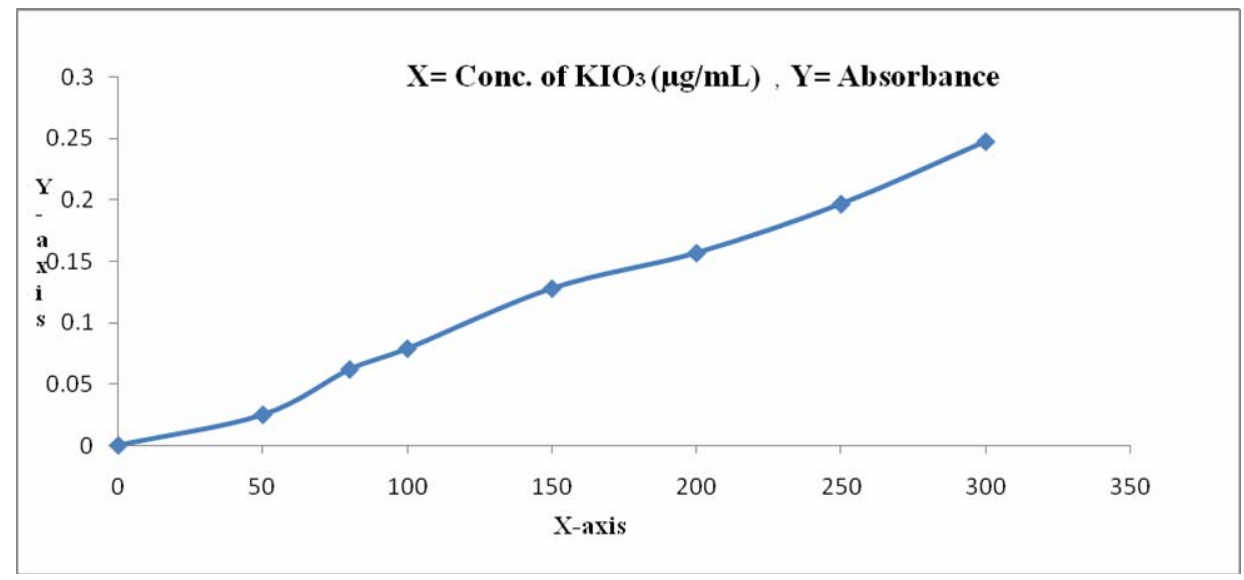

Figure 1. Absorbance Vs concentration curve of $\mathrm{KIO}_{3}$ 
From this standard curve, a straight line equation was found. The equation was, $\mathrm{y}=0.0008 \mathrm{x}-0.002$, which was comparable with the straight line equation $\mathrm{y}=\mathrm{mx}+\mathrm{c}$. The regression coefficient was, $\mathrm{R}^{2}=0.994$.

Determination of iodine. Colorimetric method was used for the analysis of iodine content in the food samples. Iodine measurement in biological samples is carried out almost exclusively by an ageold kinetic spectrophotometric method called the Sandell-Kolthoff reaction. ${ }^{8}$ The reduction of yellow $\mathrm{Ce}(\mathrm{IV})$ by $\mathrm{As}(\mathrm{III})$ to colorless $\mathrm{Ce}(\mathrm{III})$ is normally very slow. This reaction is catalyzed by trace amounts of iodide. The reaction follows the following scheme:

$$
\begin{gathered}
2 \mathrm{Ce}^{4+}+2 \mathrm{I}^{-} \rightarrow 2 \mathrm{Ce}^{3+}+\mathrm{I}_{2} \\
\mathrm{As}^{3+}+\mathrm{I}_{2} \rightarrow \mathrm{As}^{5+}+2 \mathrm{I}^{-}
\end{gathered}
$$

The difference in iodine content of samples between the control groups and the experimental groups were estimated during different cooking procedures of: 1) pressure cooking, 2) shallow frying, 3) deep frying, and 4) boiling. ${ }^{7}$

From the standard curve equation of Potassium Iodide, iodine content of food in microgram per $\mathrm{mL}$ of various food preparations before and after cooking was calculated from the following equation:

$$
y=0.0008 x-0.002
$$

Where, $\mathrm{y}=$ Absorbance of the sample and $\mathrm{x}=$ Amount of iodine in microgram per milliliter.

The loss of iodine after cooking in percentage was calculated from following equation- ${ }^{9}$

Loss of iodine in percentage $(\%)=[($ Mean Iodine content of uncooked sample- Mean Iodine content of cooked sample) / Mean Iodine content of uncooked sample] x $100 \%$.

\section{RESULTS AND DISCUSSION}

The results of iodine content of raw and cooked samples which were taken in triplicates were computed and the loss of iodine during cooking of different food preparations was calculated. This is represented in table 1 .
It was found that the percent loss of iodine ranged from $3.06 \%$ (Taki Fish Curry) to $27.89 \%$ (Masoori Dal) during pressure cooking, $14.33 \%$ (Chicken) to $32.58 \%$ (Milk) during boiling, $4.72 \%$ (Cauliflower Bhaji) to $14.42 \%$ (Bean Bhaji) during deep frying and $2.20 \%$ (Scrambled Egg) to $7.33 \%$ (Potato Bhatta) during shallow frying.

The mean losses of iodine during different cooking procedures used were pressure cooking, $13.28 \%$, boiling, $23.46 \%$, deep frying, $9.5 \%$ and shallow frying, $5.18 \%$.

Iodine content of kitchen salt was also measured for the purpose of measuring the loss of iodine during cooking of various Bangladeshi food preparations. It was observed that iodine content in a new and freshly opened pack of salt is more than a pack which was opened 1 or 2 weeks before. Some data are given in table 2.

In the present study, the loss of iodine during cooking was assessed. The minimum loss of iodine was found during shallow frying $(2.20 \%$ to $7.33 \%)$ while maximum loss of iodine was found during boiling $(14.33 \%$ to $32.58 \%)$. This could be due to the fact that during boiling, water was used for cooking the food. Salt is hygroscopic in nature and soluble in water. Hence, it absorbed water and the iodine present in the salt was leached out and lost during boiling. But water was not required as a cooking medium during shallow frying, so loss of iodine during boiling was more than during shallow frying.

From table 2 we found that the loss of iodine was ranged from $3.06 \%$ (Taki Fish Curry) to $27.89 \%$ (Masoori Dal) during pressure cooking, ranged from $14.33 \%$ (chicken) to $32.58 \%$ (milk) during boiling, during deep frying ranged from $4.72 \%$ (Cauliflower Bhaji) to $14.42 \%$ (Bean Bhaji) and ranged from $2.20 \%$ (Scrambled egg) to $7.33 \%$ (Potato Bhatta) during shallow frying. From this measurement it was observed that in cooking by same procedure, loss of iodine varied from a small amount to a large amount. This may be due to the fact that there is a strong possibility of complex formation of iodine with different food ingredients during cooking. So the variation of loss of iodine from different food 
samples in a same cooking procedure was observed. Besides, the total cooking time and cooking time of salt were different from sample to sample. Total time of cooking and cooking time of salt were higher in boiling (50 and $20 \mathrm{~min}$ in chicken curry) where the total cooking time and cooking time of salt were lower in shallow frying (3 and $2 \mathrm{~min}$ in scrambled egg). It may be another reason for the variation of loss of iodine during cooking by same procedure.

Table 1. The mean loss of iodine during different cooking procedures.

\begin{tabular}{|c|c|c|c|c|c|}
\hline Cooking procedures & Sample & $\begin{array}{l}\text { Total } \\
\text { cooking } \\
\text { time }\end{array}$ & $\begin{array}{l}\text { Cooking } \\
\text { time of salt }\end{array}$ & $\begin{array}{l}(\%) \text { Loss of } \\
\text { iodine } \\
\text { during cooking }\end{array}$ & $\begin{array}{l}\text { Mean }(\%) \text { loss of iodine } \\
\text { during different cooking } \\
\text { procedures }\end{array}$ \\
\hline \multirow[t]{14}{*}{ Pressure cooking } & Prawn Curry & $30 \mathrm{~min}$ & $15 \mathrm{~min}$ & 8.22 & 13.28 \\
\hline & Beef Vuna & $45 \mathrm{~min}$ & $25 \mathrm{~min}$ & 24.6 & \\
\hline & Masoori Dal & $35 \mathrm{~min}$ & $25 \mathrm{~min}$ & 27.89 & \\
\hline & Mugh Dal & $35 \mathrm{~min}$ & $20 \mathrm{~min}$ & 21.68 & \\
\hline & Mutton & $45 \mathrm{~min}$ & $20 \mathrm{~min}$ & 12.92 & \\
\hline & CholaVuni & $35 \mathrm{~min}$ & $20 \mathrm{~min}$ & 19.30 & \\
\hline & Rui Fish Curry & $30 \mathrm{~min}$ & $15 \mathrm{~min}$ & 12.70 & \\
\hline & Tilapia Curry & $30 \mathrm{~min}$ & $15 \mathrm{~min}$ & 8.03 & \\
\hline & Hilsa Fish Curry & $35 \mathrm{~min}$ & $10 \mathrm{~min}$ & 6.14 & \\
\hline & Mola Fish Curry & $25 \min$ & $15 \mathrm{~min}$ & 10.11 & \\
\hline & Puti Fish Curry & $30 \mathrm{~min}$ & $15 \mathrm{~min}$ & 10.54 & \\
\hline & Taki Fish Curry & $25 \min$ & $10 \mathrm{~min}$ & 3.06 & \\
\hline & Koi Fish Curry & $35 \mathrm{~min}$ & $15 \mathrm{~min}$ & 12.02 & \\
\hline & Pumpkin Curry & $30 \mathrm{~min}$ & $15 \mathrm{~min}$ & 8.75 & \\
\hline \multirow[t]{2}{*}{ Boiling } & Chicken Curry & $50 \mathrm{~min}$ & $20 \mathrm{~min}$ & 14.33 & 23.46 \\
\hline & Milk & $15 \min$ & $15 \mathrm{~min}$ & 32.58 & \\
\hline \multirow[t]{11}{*}{ Deep frying } & Vuni Khichuri & $45 \min$ & $20 \mathrm{~min}$ & 11.20 & 9.5 \\
\hline & Red Spinach Bhaji & $20 \mathrm{~min}$ & $5 \min$ & 5.17 & \\
\hline & Pui Spinach Bhaji & $20 \mathrm{~min}$ & $7 \mathrm{~min}$ & 8.19 & \\
\hline & Cabbage Bhaji & $25 \min$ & $5 \mathrm{~min}$ & 5.34 & \\
\hline & Cauliflower Bhaji & $25 \mathrm{~min}$ & $5 \mathrm{~min}$ & 4.72 & \\
\hline & Spinach Bhaji & $25 \mathrm{~min}$ & $10 \mathrm{~min}$ & 11.25 & \\
\hline & Aubergine Bhaji & $30 \mathrm{~min}$ & $10 \mathrm{~min}$ & 9.12 & \\
\hline & Cabbage Bhaji & $30 \mathrm{~min}$ & $8 \min$ & 11.74 & \\
\hline & Bean Bhaji & $35 \mathrm{~min}$ & $10 \mathrm{~min}$ & 14.42 & \\
\hline & Bele Fish Bhaji & $30 \mathrm{~min}$ & $10 \mathrm{~min}$ & 10.68 & \\
\hline & Potato Chop & $8 \min$ & $8 \mathrm{~min}$ & 12.68 & \\
\hline \multirow[t]{3}{*}{ Shallow frying } & Potato Bhatta & $10 \mathrm{~min}$ & $7 \mathrm{~min}$ & 7.33 & 5.18 \\
\hline & Green Banana Bhatta & $10 \mathrm{~min}$ & $5 \mathrm{~min}$ & 6.02 & \\
\hline & Scrambled Egg & $3 \mathrm{~min}$ & $2 \mathrm{~min}$ & 2.20 & \\
\hline
\end{tabular}

Table 2. Iodine content of marketed table salts that were used during cooking.

\begin{tabular}{lcccc}
\hline $\begin{array}{l}\text { Code of used } \\
\text { local iodized } \\
\text { salt }\end{array}$ & $\begin{array}{l}\text { Claimed amount of } \\
\text { iodine content }(\mu \mathrm{g})\end{array}$ & $\begin{array}{l}\text { Amount of iodine } \\
\text { content }(\mu \mathrm{g}) \text { just after } \\
\text { opening the salt packet }\end{array}$ & $\begin{array}{l}\text { Amount of iodine content } \\
(\mu \mathrm{g}) \text { one week later }\end{array}$ & $\begin{array}{l}\text { Amount of iodine content } \\
(\mu \mathrm{g}) \text { two weeks later }\end{array}$ \\
\hline Brand 1 & $20-50$ & 35.375 & 28.875 \\
Brand 2 & $20-50$ & 29.125 & 22.5 & 13.75 \\
Brand 3 & $20-50$ & 32.5 & 24.25 & 17.375 \\
\hline
\end{tabular}


Besides, all the samples were taken in triplicates when iodine loss was measured in both raw and cooked foods. It may also be a reason for the variation in loss of iodine during cooking by same procedure.

So far, very few studies have been conducted to assess the losses of iodine during cooking procedures. Hence, this systematic study was undertaken with the objective to assess the losses of iodine during different cooking procedures. The results showed that the loss of iodine depends upon type of cooking method and cooking time of salt. This is the first study ever done in this country revealing these facts.

The figures also indicated that iodine loss was maximum during boiling as iodine was exposed to high temperature. On the other hand, loss of iodine was minimum in case of shallow frying due to small amount of heat and less time of exposure.

The present study also reveals that besides degree of heat applied, loss of iodine also varies in various recipes. This is plausible due to a possible binding of iodine with the various components of food. Moreover, food contains many other ingredients especially many unsaturated compounds. These insaturations may also form complexes with iodine rendering less evaporation. Further research is needed to postulate this possibility.

To prevent iodine losses while cooking, it is advisable to sprinkle salt on food after cooking (wherever possible) rather than adding salt while cooking as is done traditionally in Bangladesh. Further, storage of iodized salt in a hot and humid condition near the cooking oven should be avoided. In Bangladeshi market, only $1 \mathrm{~kg}$ and $500 \mathrm{~g}$ salt packs are available. A medium family containing 4-6 members buys one salt pack for 15 days or a month. But as iodine is a volatile compound, it evaporates during storage in the kitchen near the oven. So, smaller pack size of $250 \mathrm{~g}$ or $100 \mathrm{~g}$ can reduce iodine loss from kitchen salt.

\section{CONCLUSIONS}

The results depicting the loss of iodine after cooking shall help in creating awareness among population on desirable cooking method so that the population gets iodine in adequate amount even after cooking. The information would be helpful in long run for improving the nutritional status of the population and reducing medical cost of the families.

\section{ACKNOWLEDGEMENT}

The authors acknowledge the help of Department of Pharmaceutical Technology, University of Dhaka for using the laboratory facilities.

\section{REFERENCES}

1. Kapil, U., Jayakumar, P.R., Singh, P., Aneja, B. and Pathak, P. 2002. Assessment of iodine deficiency in Kottayam district, Kerala State: a pilot study. Asia. Pac. J. Clin. Nutr. 11, 33-35.

2. Rahman, M. 2015. Comparative study of urban and rural salts for iodine content.

3. De Benoist, B., Andersson, M., Egli, I., Takkouche, B. and Allen, H. 2004. Iodine status worldwide: WHO global database on iodine deficiency. WHO, Geneva.

4. DeMaeyer, E.M., Lowenstein, F.W. and Thilly, C.H. 1979. The control of endemic goitre. WHO, Geneva, Switzerland.

5. Bhattacharjee, A., Chandra, A.K., Tabarak, T.M., Tiwari, H.K. and Mishra, A. 2013. Int. J. Biol. Med. Res. 4, 28342838 .

6. Chandra, A.K., Singh, L.H., Debnath, A., Tripathy, S. and Khanam, J. 2008. Dietary supplies of iodine \& thiocyanate in the aetiology of endemic goitre in Imphal East district of Manipur, north east India. Ind. J. Med. Res. 128, 601.

7. Karmarkar, M.G., Pandav, C.S. and Krishnamachari, K.A.V.R. 1986. Principle and procedure for iodine estimation: A laboratory manual. Indian Council of Medical Research, New Delhi, pp.1-3.

8. Sandell, E.B. and Kolthoff, I.M. 1937. Micro determination of iodine by a catalytic method. Microchimica Acta.1, 9-25.

9. Goindi, G., Karmarkar, M.G., Kapil, U. and Jagannathan, J. 1995. Estimation of losses of iodine during different cooking procedures. Asia Pac. J. Clin. Nutr. 4, 225-227. 